\title{
Door Handle Opener Controller Based on Arduino to Prevent Transmission of the Covid-19 Virus in Public Spaces
}

\author{
Sidik Susilo ${ }^{1 *}$, Erny Listijoriny ${ }^{1}$, A Wisnuadji ${ }^{1}$, Hendra $^{1}$, Dhimas Satria ${ }^{1}$, Rina \\ Lusiani $^{1}, \mathrm{~S} \mathrm{Ula}^{1}$
}

${ }^{1}$ Department of Mechanical Engineering Faculty of Engineering Universitas Sultan Ageng Tirtayasa Jl. Jenderal Sudirman Km03 Cilegon,Banten 42435, Indonesia

*Corresponding author. Email: sidik@ untirta.ac.id

\begin{abstract}
This research is to design and product design in making a touchless automatic door opener. The background of this research is to open the automatic door without touch by adding a tool or component. The purpose of this research is to open the door without a touch without changing from the door that has been made and apply Arduino technology to open the door automatically. The manufacture of this tool starts from research design, research calculations, tools and materials used, manufacture of automatic door openers, automatic door opener testing, results of automatic door opener testing, and the results and conclusions of this study. The result of this research is that the door weight is $0.03 \mathrm{~N}$ with a length of 2.1 meters, a width of 0.89 meters, and a thickness of 0.03 meters, and a door handles opening time of 11 seconds. The torque value on the door handle is $1.75 \mathrm{Nm}$ which is used to determine the minimum energy that the actuator needs to release in pushing the doorknob.
\end{abstract}

\section{Keywords: Covid-19, Door Opener, Arduino Control, Transmission Prevention}

\section{INTRODUCTION}

In early 2020, many countries are implementing a lockdown system in warding off the deadly virus. Even Indonesia experienced social restrictions in almost all regions as a result of the pandemic coronavirus [1]. Because COVID 19 can be transmitted by humans and objects of any kind, that we should be able to familiarize ourselves with no contact with any object one of them at the time of opening the door [2]. According to research by Sembiring et al. about smart door systems using internet-based ultrasonic sensors of thinks with software analysis testing methods and hardware circuit testing. In ultrasonic sensor testing, if there is a person or object in the ultrasonic sensor radar $(8 \mathrm{~cm})$, then the door will automatically open, the signal is sent to the microcontroller, which in turn opens the door. On the other hand, when there are no objects in the specified range, the door closing is activated [3]. The door remains open as long as the object is within the specified detection range. According to Ahmad Sahru Romadhon et al. [4] about the gate control system automatically using a microcontroller using the trial method, this study was conducted 50 times with five kinds of toy cars in front of the gate. In general, almost all experiments run. Properly and can open the door automatically. In the last experiment, there were two failures due to the position of the car being too close to the right or left side of the gate so that one of the ultrasonic sensors could not read. Automatic door openers are used to make it easier for humans to open doors. Efforts are given in comfort for humans is in developing automatic systems on doors. The automation system used previously was by changing the shape of the door. In this case, this study examines how to open the door automatically without changing the shape of the door [5].

The coronavirus can be transmitted from human to human when the human transmission is usually through coughing or sneezing. If it is inhaled or in contact with the eyes, the person is at risk of contracting the coronavirus [6].

Because Covid-19 can be transmitted from touch, we must get used to reducing touch to things that are touched by other people, one of which is the door. With Arduino 
technology, it is hoped that it can break the chain of the spread of the Covid-19 virus because it will use sensors that read input, so that produces output door open and close automatically without touch.

\section{METHODS}

One of the ways to prevent the spread of the virus is not to touch the things whose suspected touch it. Arduino is an open-source microcontroller system for creating electronic projects. Arduino is a derivative of the Wiring Platform. The purpose of the Arduino is to make it easier to engineer electronics in applications in various fields of electronics [7]. The hardware of Arduino is to use the Atmel AVR processor with its own programming language.

Therefore, it is necessary to find a method how to prevent coronavirus 19 spread via a door. Because Covid-19 can be transmitted from touch, we must get used to reducing touch to things that are touched by other people, one of which is the door, with Arduino technology, is expected to be able to break the chain of the spread of the Covid-19 virus because it will use an ultrasonic sensor that reads the input so as to produce the output of the door opening and closing automatically without touching.

The Arduino system uses an automatic sensor system. Arduino is an open-source electronic kit that contains a microcontroller with the AVR type. The microcontroller can be programmed using a computer. In embedding the program, it can read input, process input, and produce output as desired.

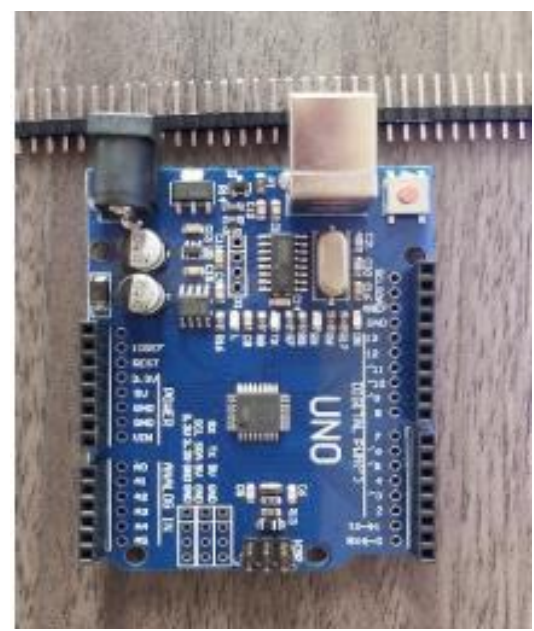

Figure 1 Arduino board circuit.

The ultrasonic sensor functions as the transmission of ultrasonic waves at speeds above human hearing. Ul- trasonic sensors are used as data collectors. The ultrasonic sensor consists of an ultrasonic wave transmitter and an ultrasonic wave receiver [8]. The working principle of the sensor itself is based on the reflection of a sound wave so that it can be made to interpret the distance of an object with a certain frequency. The working principle of the ultrasonic wave ultrasonic sensor is switched on with a tool that is piezoelectric with a certain frequency. The piezoelectric function is to shoot ultrasonic waves towards an area or object. After the wave hits the surface, the target will reflect the wave back. The reflected wave will be captured by the sensor, then the sensor is the difference between the time of sending the wave and the time of the reflected wave being received [9]

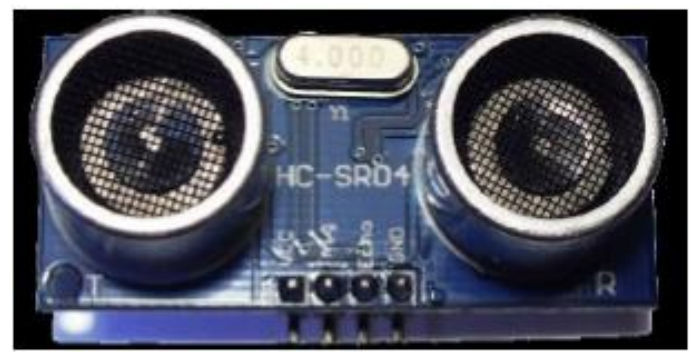

Figure 2. Ultrasonic Sensor.

In this study designed an automatic door handle control system that can open the door automatically if in front of the door there is a hand wave. In this research, two ultrasonic sensors are placed in front and on the back so that it can detect a hand waving properly. The automatic door control system process utilizes Arduino Uno $\mathrm{R} 3$ is a microcontroller that is connected to two ultrasonic sensors, a DC motor as a driver for the door handle. Each component is connected to the LM2596 step-down, which is used to lower the voltage so that all components are safe and acceptable to the microcontroller.

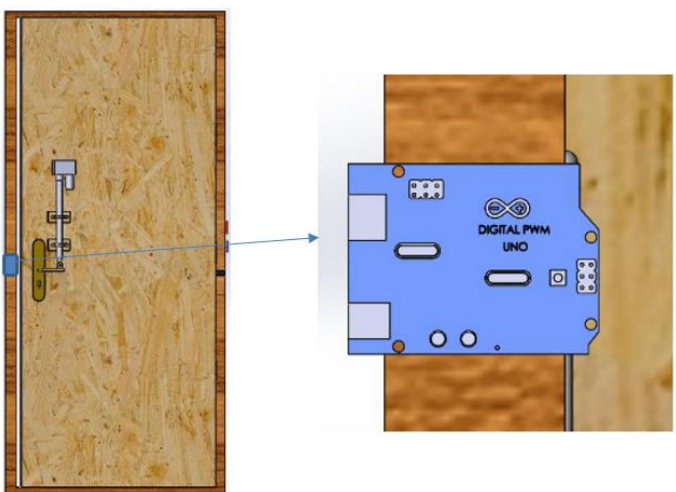

Figure 3 Location of the sensor and actuator motor 


\section{RESULTS AND DISCUSSION}

In this study, testing tools were carried out on the prototype of the Arduino-based automatic door handle control system, which aims to be able to find out whether the entire circuit is working as expected. The actuator is placed above the door handle. So that the actuator does not fall, it is clamped to the door. The actuator can push and pull the doorknob by connecting the doorknob and the actuator. Connectors are used using coupling.

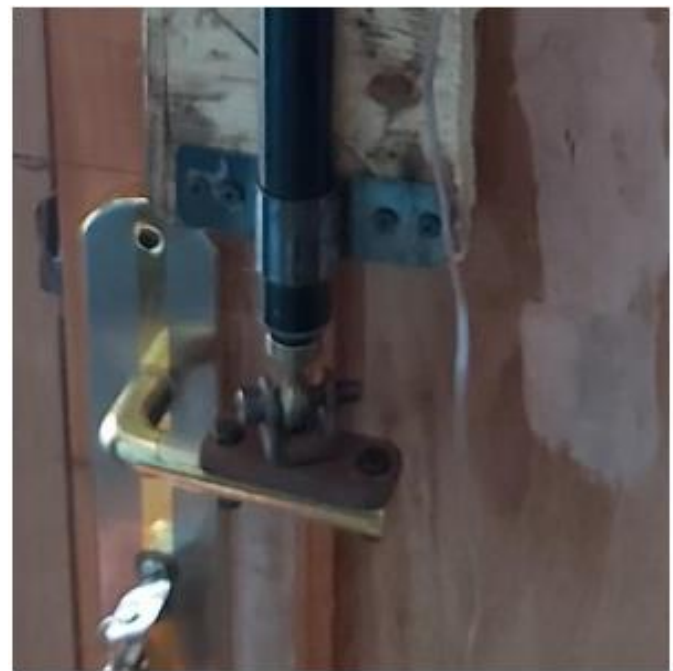

Figure 4 Actuator.

In looking for the time to open the doorknob, you get the speed of the actuator is $0.005 \mathrm{~m} / \mathrm{s}$ or $0.5 \mathrm{~cm} / \mathrm{s}$ with a voltage of 24 volts on the actuator as shown in figure 4 . The length of the track on the handle when opening the door is $55 \mathrm{~mm}$ or $5.5 \mathrm{~cm}$. So the time it takes to open the door is

$$
t=\frac{s}{v}
$$

Based on door properties; the door weight is $0.03 \mathrm{~N}$ with a length of $2.1 \mathrm{~m}$, a width of $0.89 \mathrm{~m}$, and a thickness of $0.03 \mathrm{~m}$. Finding torque in automatic door opener is as follows:

$$
\tau=F \times l
$$

From the testing in this study, it was found that the ultrasonic sensor can capture the wave of the hand which then moves the actuator to open the doorknob in 11 seconds and with a torque of $1.75 \mathrm{Nm}$.

\section{CONCLUSION}

The manufacture of this tool starts from research design, research calculations, tools and materials used, manufacture of automatic door openers are presented in this study. The result of this research Door handles opening time of 11 seconds and the torque value on the door handle is $1.75 \mathrm{Nm}$ which is used to determine the minimum energy that the actuator needs to release in pushing the doorknob can be realized.

\section{ACKNOWLEDGMENT}

This research is carried out in the Manufacturing Laboratory Department of Mechanical Engineering, Faculty of Engineering, Universitas Sultan Ageng Tirtayasa.

\section{REFERENCES}

[1] Moudy J, Syakurah RA 2020 Pengetahuan terkait usaha pencegahan coronavirus disease (COVID-19) di Indonesia Higeia J Public Heal Res Dev. 4(3):33346.

[2] Nesteruk I 2020 Statistics-based predictions of coronavirus epidemic spreading in mainland China. Innov Biosyst Bioeng. 4(1):13-8.

[3] Sembiring A, Lubis MRP 2018 Prototype buka tutup pintu berbasis arduino uno dan android. J Teknol dan Ilmu Komput Prima. 1(1):77-84.

[4] Romadhon AS, Anamisa DR. 2017 Sistem pen-gendali pintu pagar secara otomatis menggunakan mikrokontroller. Semin Nas Teknol dan Rekayasa. 1-4.

[5] Suradi S, Haslindah A, B N, Dindayatie A 2019 Perancangan sistem buka tutup pintu rumah menggunakan android berbasis arduino. ILTEK J Teknol. 14(01):2006-10.

[6] Sepriani R, Delyana H, Hafizah, Rusdinal, Gis-tituati N 2021 The role of parents to enlarge stu-dent s interest in learning during the covid-19 pandemic : a case study in Indonesia. Eur J Educ Stud. 8(5):197-205.

[7] Aziz A, Roossano A. 2016 Desain dan prototipe kunci pintu otomatis menggunakan rfid berbasis arduino uno. Ilm Inform dan Komput. 21:86-93.

[8] Arsada B 2017 Aplikasi sensor ultrasonik untuk deteksi posisi jarak pada ruang menggunakan arduino uno. J Tek Elektro. 6(2):1-8.

[9] Carullo A, Parvis M 2001 An ultrasonic sensor for distance measurement in automotive appli-cations. IEEE Sens J. 1(2):143-7. 